\title{
Some Student Teachers' Conceptions of Creativity in Secondary School English
}

\author{
Beth Howell \\ School of Education, University of Durham \\ Leazes Road, Durham, DH1 1TA, U.K. \\ Tel: 44 -191-334-8352Ｅ-mail: Beth.Howell@dur.ac.uk
}

\begin{abstract}
This article explores a group of trainee teachers' conceptions of Creativity in Secondary School English. Data was collected by means of questionnaires and interviews. Whilst there are many promising notions of creativity, the results also reveal some evidence of narrow conceptions, inconsistent thinking and some misconceptions. This suggests that there may be significant implications for teacher trainers in universities and schools if we are to equip our students with the knowledge, understanding and skills to teach, support and facilitate creativity in their new careers. Romantic notions of original and innate genius, and a progressive emphasis on boundless, directionless play are two possible sources of misconceived ideas for training teachers of English. Creativity can be supported and developed within pedagogical frameworks and settings. This article, therefore, offers a consideration of how Sternberg's 21 suggested strategies for "Developing creativity as a decision" might be adapted and implemented in the Secondary English classroom. Practical teaching methods and competencies are presented which could be developed and incorporated into graduate trainee teacher programmes.
\end{abstract}

Keywords: Creativity, Trainee teachers' conceptions, Pedagogical implications.

\section{Introduction}

\subsection{Creativity}

Creativity is the process of making connections and, sometimes, is about productivity, about making something new from those connections (Gardner, 1993, Sternberg 1988, 2003, Newton \& Newton, in press). Creating spaces where these symbiotic activities can take place is an exciting and pedagogically sound venture. Creativity is also about problem solving (Gardner, 1993, Sternberg 2003), an essential life skill which can be explored in the Secondary English classroom. Sternberg's 'investment' theory of creativity (2003) and Robinson's theory of how to promote creativity (2001) point to the complexities of the relational and human resources required when creative activity is at play. "Intellectual skills, knowledge, styles of thinking, personality, motivation and environment" all take key parts and work together to open up the space for creativity (Hall and Thomson, 2005, p.15). Creativity has an impact on self-esteem, social skills and strategies which are valuable for life-long learning (Sternberg, 2003, Craft, 2002). The effect of creative teaching and learning on children's personal development has been well documented (NACCCE, 1999; QCA 2003, 2005; SEED, 2006; Ofsted, 2006). The word 'creative' has been writ large in many educational and curriculum reforms both in the United Kingdom and abroad (see Fleming's full and comprehensive review of Arts and Creativity in Education, 2008, Le Métais' international exploration of national values and educational aims, 1997 and Hopkin's account of the Toronto Board of Education Curriculum Revision and Reorientation, 1997). This study was undertaken as a response to and in anticipation of the focus on creativity in the new curriculum which will be implemented in September 2008 in England; this curriculum has 'creative thinking' as one of its central aims. In order to train new teachers to implement creative strategies and foster creative activity in the classroom, we need first to be clear about what they consider creativity to be. Weston (2007) and Sternberg (2003) argue that creativity can be taught, learnt and developed within pedagogical settings. Both these authors offer practical guides to this effect. Drawing on Sternberg's 21 suggested strategies for "Developing creativity as a decision" (Sternberg, 2003, pp. $110-123$ ), it is useful to consider which of these enter into trainees' pedagogical thought and therefore evaluate to what extent training teachers are equipped to implement these in the classroom and thus fulfill the aims of the new National Curriculum in England. 
Sternberg offers general explanations alongside some specific practical illustrations of strategies which would facilitate the conditions for creative teaching and learning under the following headings:

\begin{tabular}{|c|c|c|}
\hline $\begin{array}{l}\text { Redefine Problems, } \\
\text { Ouestion and }\end{array}$ & $\begin{array}{l}\text { Encourage } \quad \text { Tolerance of } \\
\text { Ambiguity, }\end{array}$ & $\begin{array}{l}\text { Reward Creativity, } \\
\text { Allow Mistakes, }\end{array}$ \\
\hline $\begin{array}{l}\text { Assumptions, } \\
\text { Do Not Assume that Creative }\end{array}$ & $\begin{array}{l}\text { Help Children } \\
\text { Self-Efficacy, }\end{array}$ & $\begin{array}{l}\text { Take Responsibility for Both } \\
\text { Successes and Failures, }\end{array}$ \\
\hline $\begin{array}{l}\text { Ideas Sell Themselves: Sell } \\
\text { Them, }\end{array}$ & $\begin{array}{l}\text { Help Children Find What They } \\
\text { Love to Do, }\end{array}$ & $\begin{array}{l}\text { Encourage } \\
\text { Collaboration, }\end{array}$ \\
\hline $\begin{array}{l}\text { Encourage Idea Generation, } \\
\text { Recognize That Knowledge Is a }\end{array}$ & $\begin{array}{l}\text { Teach Children the Importance } \\
\text { of Delaying Gratification, }\end{array}$ & $\begin{array}{l}\text { Imagine Things from Other's } \\
\text { Points of View, }\end{array}$ \\
\hline $\begin{array}{l}\text { Double-Edged Sword and Act } \\
\text { Accordingly, }\end{array}$ & $\begin{array}{l}\text { Role-Model Creativity, } \\
\text { Allow Time for Creative }\end{array}$ & $\begin{array}{l}\text { Maximize Person-Environment } \\
\text { Fit }\end{array}$ \\
\hline $\begin{array}{l}\text { Encourage Children to Identify } \\
\text { and Surmount Obstacles, }\end{array}$ & $\begin{array}{l}\text { Thinking, } \\
\text { Instruct }\end{array}$ & \\
\hline $\begin{array}{l}\text { Encourage } \\
\text { Risk-Taking, }\end{array}$ & Crec & \\
\hline
\end{tabular}

(Sternberg, 203, pp. 110 - 123).

Each of these pedagogical strategies is adaptable for specific subject areas such as English. They are also useful for categorizing into themes the conceptions which the trainees have offered in their questionnaires and interviews. Teacher trainers may then address any neglected or misconceived areas and consider how to prepare future student teachers.

\subsection{Creativity in English}

Origins of misconception may be connected, in part, to the Romantic literary tradition and its philosophy regarding creativity and the imagination. In 1797, Samuel Taylor Coleridge famously composed his poem "Kubla Khan: Or a Vision in a Dream. A Fragment" and then published it "rather as a psychological curiosity, than on the ground of poetic merits". The poem, he claimed, came to him effortlessly, the images rising up unconsciously as he slept. When he awoke, he wrote down all that he could recollect of his vision before he was interrupted by a visitor, the rest was lost (Bloom and Trilling, 1973, pp. 254-255). This account of an extraordinary event serves well as an illustration of an attitude towards original genius, the muse and the unconscious which saturates Romantic ideas about creativity whereby the isolated artist becomes a channel for some kind of divine inspiration. This view leaves little room for the notion of fostering creativity in the English classroom. It is worth noting that a significant number of post-graduates who opt for teacher training in Secondary English in the U.K. have studied Romantic literature in some depth. A narrow or misconceived view of creativity may be a result of this ideology. Weisberg's interrogation of such myths surrounding conceptions of creativity are insightful (Weisberg, 1986, 1993). He points out that at least two versions of "Kubla Khan" exist and this suggests that the poet consciously crafted and edited the work before it was published (Weisberg, 1986, p.115).

Another pit-fall for trainees' thinking about creativity is the 'free-for-all' notions which, in the United Kingdom, were supported by progressive ideology and its effect on English teaching in the 1960s. Both Abbs (1982) and Craft (2002) offer a useful history and evaluation of teaching methodology during this period and highlight its flaws. The progressive movement, which had as its central aim child-centred, experiential, spontaneous learning, may be held partly responsible for many misconceptions which undermine the teacher's role: "It paved the way to a spurious notion of creativity, a notion which lacked reference to any cultural context, any evolving mastery of form, any adult guidance and criticism" (Abbs, 1982, p.5). However, as Fleming (2008) argues, a fair evaluation of the influences of progressive ideology would place the emphasis on child centred learning in its context as an important reform of traditional rote learning and straitjacketed prescription. What we need now is a balanced approach which aims to engage the child in enjoyable and pedagogically worthwhile activities where they will both learn from their teachers and have the freedom to explore, discover and retain ownership of their learning (Fleming, 2008, p.24).

The notion of teacher as a facilitator, rather than an expert who will intervene, guide and teach, is an issue teacher trainers in the expressive arts subjects may need to address. Children need instruction and explanation of content, form and technique if they are to use the skills necessary to think or act creatively (Craft, 2002). Also, if trainee teachers conceive of creativity as being related to critical thinking skills and problem solving (Sternberg 1999, Weisberg, 1986), 
then they can perhaps begin to understand that the idea of boundaries and training in creativity is beneficial. Teachers do need to create spaces for creativity, both physical and conceptual but there needs to be structure in order for this to be successful. Boden (1996) argues that there needs to be constraints and these emerge from an understanding of the domain and knowledge of the skills needed to produce or to think something which will be valued as creative: "The dimensions of a conceptual space are the organizing principles that unify and give structure to a given domain of thinking" (Boden, 1996, p. 79). We can modulate, challenge and reframe once we understand what the frame is and of what it consists.

\subsection{Creativity in the English Classroom}

English is vital for communicating with others in school and in the wider world, and is fundamental to learning in all curriculum subjects. In studying English, pupils develop skills in speaking, listening, reading and writing that they will need to participate in society and employment. Pupils learn to express themselves creatively and imaginatively and to communicate with others confidently and effectively.

Literature in English is rich and influential. It reflects the experiences of people from many countries and times, and contributes to our sense of cultural identity. Pupils learn to become enthusiastic and critical readers of stories, poetry and drama as well as non-fiction and media texts, gaining access to the pleasure and world of knowledge that reading offers. Looking at the patterns, structures, origins and conventions of English helps pupils understand how language works. Using this understanding, pupils can choose and adapt what they say and write in different situations, as well as appreciate and interpret the choices made by other writers and speakers.' (QCA, 2007)

For 'English' read any native or additional language. In England, the new Framework for Secondary English proposes many learning objectives which relate to creativity (QCA, 2007, 2008; DfCSF, 2008). With regard to pupils' use of style, structure, vocabulary and grammar in their writing they need to be able to apply what they have learnt about linguistic and literary techniques "accurately, creatively and appropriately to achieve impact and effect." Pupils need to make "considered choices", demonstrate independence and draw on "conventions and structures in order to achieve original and inventive impact and effect" (QCA, 2008; DfCSF, 2008)). Creativity is about process, problem solving and thinking skills as well as product. In this respect, reading, discussion, and drama also offer creative activity in the English classroom. Imagining alternative worlds through reading fiction can enable children to develop coping strategies for their own lives. Critical analysis, personal response to and interpretation of texts also enables children to develop their creativity. Knowledge and understanding of ethics, human empathy and citizenship can be taught and learnt through reading in English lessons. Given that empathy and critical enquiry are central to creative teaching and learning in English, we need to be sure that student teachers share this view and are able to prepare and deliver lessons where these processes can take place.

\section{Method}

\subsection{Context}

Teacher training practices vary from country to country. Most secondary school trainees in the United Kingdom follow a one year postgraduate programme which involves study at a university as well as teaching practice in a school placement. This study explores what 'Creativity' means to a group of post-graduate trainee Secondary English teachers in the North East of England. Conceptions of creativity were first investigated and identified through questionnaires at the very beginning of their one year course and before the trainees' first school teaching placement. Semi structured interviews followed after the students had experienced four weeks of teaching English in a Secondary school. During this period they were responsible for planning and delivering lessons, assessing pupils' work and evaluating their own performance in the classroom.

\subsection{Participants}

There were 17 participants in the group. They were randomly selected from a larger cohort of 45 Secondary English teacher trainees. There was a range of abilities within the group which was indicated through formal assessment and participants ranged in age from 21 to 36 years. Two thirds of this group had first degrees in English Literature, the rest had degrees in Media Studies, Linguistics, English and Education Studies, English and History and Philosophy. Although there was a clear gender imbalance ( 2 male and 15 female), a fair reflection of the ratio of male to female trainees who opt to train to teach Secondary English at our institution, the responses did not indicate that gender was a significant factor in determining the trainees' conceptions.

\subsection{Questionnaire}

Briefly the questionnaire was designed to explore: conceptions of creativity in the context of the English classroom with specific examples from their experience of teaching and learning so far; what trainees considered to be evidence of creative thought / work; what would they value as being creative and why; whether they thought that encouraging creativity in English was easy or hard; what they thought the teacher's role was; and whether they conceived of problem 
solving as being related to creativity (see Appendix A).

\subsection{Interviews}

A third of the cohort were interviewed after the trainees' first school placement which consists of four weeks of close classroom observation and then four weeks of planning for and delivering their own lessons across a range of ages and abilities in Secondary Schools in the North East of England. The interview questions were devised to elicit clarification and expansion of the categorized ideas and themes expressed in the questionnaires and the participants were able to give specific practical illustrations based on their experiences in schools.

\subsection{Marton's Phenomenographical analysis}

The responses in the questionnaires were categorized following Marton's method of phenomenographical analysis (1981). This amounted to an iterative sort of responses into groups of conceptions under distinct headings. This process enabled further grouping of the descriptions regarding the trainee's notions of creativity into related categories. Also, the data revealed some overlap and blurring of boundaries between the categories of ideas expressed. Emerging patterns and tensions between categories were further explored in the ensuing interviews. The list of categories presented in this paper may not be complete; a larger sample could add new categories. However, those described here are able to inform discussion and reveal implications for teacher trainers. The data also points to different areas for further study in different contexts and countries.

\section{Results}

An informal examination of the responses in the questionnaires suggested that there were recurring themes in the students' expression of creativity in English. These are presented in figure 1.

$<<$ Insert Figure 1 approx. here $>>$

There were many interconnections and evidence of some overlapping concepts, inconsistencies or incoherent thinking within some of the participants' questionnaires. As a response to the categories emerging from the questionnaires, the following themes were areas for further exploration in the interviews:

- Nature of English with regard to creativity drawing on specific examples from the classroom

- The relationship of creativity to the imagination

- The Teacher's role: framework, structure and intervention versus freedom, choice and autonomy

- Trainees' Concerns

Conceptions regarding individuality, self-expression, freedom and autonomy were also explored further in the interviews. Responses gathered from both the questionnaires and the interviews revealed consensus, tensions and contradictions including misconceptions and inconsistent thinking, neglected areas and trainees' concerns. Each of these will be discussed in turn.

\subsection{Consensus}

Creativity was conflated with original thought, going beyond standard ideas and exploring beyond the obvious. The cliché "Thinking 'outside the box" was a repeated phrase. One participant who thought that creativity was demonstrated by the ability to look at things in different ways also suggested that children are more able to do this because they are less "restrained in terms of rules" than adults. Adults become restrained as they become integrated into society but children still have the freedom to think about things in ways that are out of the ordinary. Based on her own experiences at school confidence to express one's own ideas was of central importance; she felt that it was important that children should be encouraged to express their individual ideas even if they were different to other people's without fear of being wrong:

"I would try to encourage that individuality and repeat that there isn't always a right or wrong answer, there's more than one answer. English definitely lends itself to that, to be able to express yourself and how you think as an individual because if you can't you're stuck in a box and not able to talk really."

Exploring, playing with and manipulating language to create effect was seen as part of the creative process. A majority of trainees considered creativity to be evidenced in novel products. Creative work or products would be valued if they were interesting, out-of-the-ordinary and engaging. In terms of originality and novelty one participant articulated the distinction between creativity as product and process in interview; he explained that he saw creativity as relating to process but also mainly concerned with productive activity:

"My loosely conceived idea of creativity has always involved the idea that it is something that has been produced now, in that moment, in that process. Something that wasn't there before. If it was there before then in a sense it's not creativity as a lot of people would understand it."

Self-expression and production of original texts was seen by most within this cohort as a creative opportunity offered in 
English lessons. There was an emphasis on individuality and subjective response embedded within this group's conceptions of creativity in English. Creativity was associated with independent thinking: "I associate creativity with learning to think by yourself, independent thought and sometimes learning to think in quite abstract ways as well." Another example of the emphasis on individuality emerges here: "English offers a unique opportunity for students to show off their creative flair in their own original writing". This interviewee thought that students enjoy English more at university because, as regards interpretation of texts, in schools there is a "given" response that teachers or examiners are looking for. "Essentially creativity and English marry very well together because there aren't any absolute answers. That's what drew me to English, I disliked the idea that you can be absolutely right or absolutely wrong."

Using one's imagination was seen by over half the group as being synonymous with being creative: "English is a creative subject because it allows children to let their imaginations run riot in writing poetry and stories. Also reading itself develops imagination which is the root of creativity." Ideas which were contrary to notions of structure and conscious control and highlighted the close relationship between creativity and the imagination were interrogated further through the interviews. Participants were asked to explain how they saw the relationship between Creativity and the Imagination. This question stimulated different responses but each respondent saw strong links between creativity and the imagination. In one response the boundaries between the two are quite blurred:

"I always think the imagination is that extra stretch. You might have creativity there but the imagination is that extra stretch to get to expressing the creativity. Again, it's an individual thing - I do think that imagination and individuality are connected. Everybody's imagination is going to be different. The way you perceive things. You have to have a bit of imagination to be able to be creative in some way. Once you've become comfortable with the notion of creativity and the imagination maybe then you become more confident to be able to express them. To become more creative and imaginative."

One candidate thought of the imagination as being necessary for creativity but explained that she saw this relationship as "one-way":

"I see creativity in terms of creative process and something achieved at the end. Whereas, for me, imagination's more of an outlet for everything you've got going on. Imagination kind of feeds your creativity but it's that kind of one way relationship. I don't see it the other way round."

Another view attempts to make a clear distinction: "I wouldn't say that the imagination works in symbiosis with creativity because I think that sometimes imagination can draw you back in some ways. You need it to take you somewhere and sometimes imagination can be somewhat overwhelming. There are similarities between the two but sometimes the imagination can be too wayward so then you couldn't put it to good use. If used constructively imagination can push the creative limits. You need to stream it in the right way."

Another participant attempted to articulate a conceptual distinction between creativity and the imagination which related to control: "I think that creativity is probably more consciously orchestrated than imagination." This conscious (autonomously willed) orchestration of creativity was conceived of as organic rather than mechanistic.

It is not within the scope or aims of this paper to explore further these interesting and various ideas about the relationship between the imagination and creativity here since the evidence would suggest that these conceptions would not hinder trainees' ability to foster creativity in Secondary English. Writers such as Abbs (1976, 1982), Egan (1992), Harrison (1994) and Fleming and Stevens $(1998,2004)$ offer useful insights into the place of the imagination in English teaching.

\subsubsection{The Teacher's Role}

The main area which emerged from the responses to the questionnaires which merits further discussion is the trainees' expression of how they conceived of the role of the teacher. Eagerness and pupil participation was considered to be an outward sign of creative thought and activity. Children need to be interested in order to be creative. The teacher's role then is to entice, engage and stimulate this kind of response. In the interviews participants were invited to explain their conceptions of creativity with illustrative examples from English lessons they had observed or taught. Examples of teacher intervention included teachers modeling creativity, teaching basic skills and frameworks with which children could be creative and engaging children by offering interesting or unusual work. Four trainees conceived of English as a creative subject because of the variety of activities and texts it offers. Five trainees offered examples of creativity in English which had cross-curricular links to other subjects (Art and Music in particular). Examples of creative teaching involved cross-fertilisation, the unexpected and quick thinking in order to motivate and engage pupils. One interviewee gave the example of an unusual activity which stimulated quick-thinking; the teacher threw a football to randomly selected pupils who had to think of an adverb by the time they had caught the ball.

\subsubsection{Relevance}

Two trainees said that teachers could inspire children to be creative by making work relevant; children can be engaged 
by drawing on prior knowledge, this helps them to make connections to their own lives. For one participant creative teaching is all about "offering different ways into texts or topics" which are engaging and relevant to the pupils so they can make connections to "real life". This was illustrated with an example of a teacher who had brought in media material about serial killers to stimulate engagement with poetry about murder: "to give a different real life perspective - something real to point to. All of a sudden it wasn't so remote and far removed and they could see what it actually meant." Relevance was also important to another participant; she said that making texts or tasks relevant to pupils so that they could make connections to their own lives was a creative teaching method.

\subsubsection{Valuing}

The importance of valuing creative ideas is included in the teacher intervention category; three trainees wrote about this in their questionnaires. Valuing among these trainees is linked to self-esteem and confidence building. Here the need for valuing in order to create the conditions for creativity is clear: "In some cases it is hard as in Secondary at some ages pupils find it embarrassing to demonstrate creative thought. However, once one pupil suggests something which is received well this usually sparks debate." The importance of valuing in terms of encouragement was also linked to confidence and motivation: "As soon as you say to a child 'oh, that's a good idea, that's a different way of thinking', they immediately become willing to take that further and try to think a little more."

\subsubsection{The Pupils' Personality and Emotions}

This data reveals trainees' ideas about the personality traits needed in order to be creative, confidence in particular emerged as being necessary for self-expression and one trainee said that sharing ideas required trust. Confidence was also related to the question about encouraging creative thought. Two participants explained that this is hard because:

(a) "There is a certain amount of trust involved, as putting something you have created out into the world can be a traumatic experience."

(b) "It is a confidence thing - creativity often comes from deep within and teenagers are often embarrassed to share their intimate thoughts or opinions."

\subsection{Contradictions and tensions}

Nearly all the trainees were clear that teachers should be creative in their planning and in their manner of encouraging and supporting creative activity. However, there was a blurring of conceptions as regards intervention and facilitation.

\subsubsection{Freedom versus Frameworks}

Tensions emerge within the responses which describe or explain the teacher's role when absolute freedom of choice and introduction of activities which do not follow rules are conceived of as examples of creative teaching in English. These trainees thought that having no constraints or barriers, no fixed or correct outcomes was desirable. Less than half the group thought that teachers should teach for creativity and that pupils need frameworks and guidance from teachers in order to use the skills required to produce valuable original work or insightful interpretations of texts. A majority of the participant trainees thought of English as a creative subject because analysis and interpretation of literature and language invites personal and individual interpretations: "Poetry is open to personal interpretation. There is rarely a set or correct 'answer' to poetry, so children can be creative in how they analyse it and how they choose to view it." Here is an example of the blurring of boundaries between teacher interventions in terms of instruction and support and the notion of creativity as being boundless: "Sometimes confidence (or lack of it!) gets in the way of creative thought. Pupils are so used to being given a framework to work by but creative thought by its very nature has no boundaries. Maybe a combination of a loosely structured framework and freedom would help."

Evidence from the interviews revealed some understanding of the need for frameworks, guidance and teaching of skills:

"I like the idea that I'm there as a tool and not for me to say 'you have to do this, this and this. By the same token you have to understand that younger children especially don't have the confidence to just do something. So I'll give them a framework or guidance but then they have to be - I remember describing it as organic and allowing for room to let them express their ideas and to feel safe to express those ideas. Not that there's one set things and they have to get the answer right or wrong or whatever".

The idea further expanded here was that, in order to create the conditions for creativity, the teacher would need to create space for the pupils but also enclose them within a safe environment. Teacher intervention would involve sharing knowledge and understanding, inviting children to be creative but also realising that pupils need to know the skills and techniques: "They need the skills in order to be creative because if you just create space without any skills then you're just left in a kind of no-man's land and don't know how to express those things in the way that you might want to."

In her questionnaire another participant had written that pupils need self-confidence in order to express their creativity. I asked her to clarify further whether she had meant confidence in 'self' and to say whether or not she still held this view. Her answers provide evidence that she is now relating confidence with knowledge of skills. Evidence of a moderation 
of ideas regarding teacher intervention following is clear in this instance:

"I think that at the time of writing this it was about confidence in your self. Since then and the experience I've had in schools, I can understand the skills side of it. If you've been given the tools to use, the skills, or if people have guided you how to use them, that boosts your confidence and you've got more understanding of what you're doing. If you know you're using the skills correctly and you've been shown that that's acceptable then you've got more confidence to do that. If everyone in class is using the same skills then it's not like you're standing alone."

This interviewee understood the foundational value of teaching pupils the knowledge and understanding of skills: "It builds the foundations. Then you put your own ideas in and your own little bit of creativity to build up from there." She also saw the need for balance as regards choice and structure - pupils need "room to manoeuvre" without feeling limited. In her questionnaire she had written about giving children a free rein with no barriers and no structure. Her experience in schools had tempered that view. She had observed a teacher giving pupils a range from extracts from different writers in order to explore with them the effects of different literary techniques before they began their own original writing coursework:

"I can understand now how that can be difficult for children, not being told 'this is what you need to do'. They need to know what good writing looks like, what techniques they can use so they can make decisions. No barriers and no structure is too much scope and that results in 'I don't know where to go next and I don't know what to put in there. Without limiting they do need some guidance and support."

\subsubsection{Inconsistent thinking}

The data collected through the interviews reveals that some of the trainees' thinking had been modified by the experience of being in school. However, there was still evidence of narrow conceptions, misconceptions and inconsistencies within the participants' understanding. For example, one trainee did emphasize the importance of group work and classroom display as being conducive to creative teaching and learning. However, this trainee also thought that a creative child might be "eccentric" and isolated from his peers. This participant had also linked creativity to ability in her questionnaire and she had written that creativity is "innate". I asked her to explain further in her interview:

"I do think that there are certain individuals born with a certain amount of creativity and sometimes that can be stifled in school or sometimes it can be developed in a very creative environment. I do think that some people have it or not. You know, you're born with it but the right sort of teaching can really develop that."

Another trainee intelligently highlighted the distinction between creativity as process rather than product. Creativity is difficult to observe, she suggests, because "it might be the process leading up to the product, rather than the product itself which is creative." However, this trainee also expressed her frustration that "inferences" should be taught and that pupils were expected to give "right" answers. She felt that children should be encouraged to think that, as regards interpretation of texts, there are no right or wrong answers, that their individual and personal responses are what matters most.

\subsection{Neglected areas}

It is noteworthy that only three trainees related creative activity in English to discussion, debate and collaborative work. No one wrote about physical space or the classroom environment in the questionnaires as being important for establishing the conditions for creativity. Two trainees offered conceptions which related creativity to a world view: "Creativity in English is about approaching ideas and concepts in different lights, exploring and conceptualizing them in different forms. It is about imagination and originality, not just in the creation of original pieces of work but in the way we view the world."

\subsubsection{Empathy}

Within those answers which linked creativity to emotions and feelings, only two trainees wrote about the development of empathy in the questionnaire as being an opportunity provided within English. A promising response offered empathy through role play as an example of a creative lesson: "creating a part and thinking creatively about how someone else would feel in certain situations, thinking outside of own personal experience / ideas is creative."

\subsubsection{Problem Solving}

Two trainees related empathy to problem solving in English lessons:

"Problem solving involves identifying the different elements of the problem and deciding on how to approach it. This involves an open and creative mind and being able to bring different concepts together to find a solution. An example of problem solving in English - analyzing a poem involves identifying the key issues, using the skills they have learnt elsewhere and bringing all their knowledge together to decide what the poem is about."

The second trainee related problem solving to life long learning and skills needed beyond the English classroom: 
"Empathy and understanding are built upon communication. Being able to express yourself fluently means you will be able to understand and be understood by others which means you are more likely to get to the position you want to be. These can be theoretical subjects in a class debate or at home when negotiating with family."

Experiential learning was offered by two trainees as an opportunity for creativity in English in the interviews. One participant described a teaching method which helped pupils to understand the text through experiencing what the character was experiencing (empathy) - being shut in a totally dark room. Another participant also gave as an example experiential learning linked with empathy. Here the teacher was modelling creativity, she suggested, by lying curled up on the floor while the students shouted Shakespearean insults at her.

\subsubsection{Questioning}

Criticality, reflection and questioning were only brought into discussion about creativity by two trainees in interview. One participant thought that the process of creativity was about asking oneself questions about decisions and choices providing oneself, for example, with a simultaneous rationale whilst writing or reading. This stimulates criticality which is creative. Being curious without actually needing definite answers is part of the creative process. Another participant saw creativity as being related to questioning in a reflective and critical sense. Evidence of creative thought would be questioning any: "frameworks which are prescribing a process - 'this is how we go about it'. For me, creative thinking would involve first and foremost trying to unpack and rework some of the assumptions that are implicit in the question. I suppose that in a sense creativity is metacognitive."

\subsubsection{Conditions for Creativity}

One interviewee gave an example of a creative classroom or environment as one where there would be "lots of different sorts of group work where pupils have to draw on things from their own experience." A creative classroom would be colourful with lots of displays of pupils' creative work. This would be visually stimulating and create a positive environment. The arrangement of tables would be set out for group work and that there would be flexibility so that practical spaces could be provided for drama activities. However, she considered collaborative work she had observed was successful because "the more creative ones were engaging the less creative ones and helping them to think outside the box". "The box" as she conceived of it was "a very traditional school of thought from education, probably pre-1960s which includes rote learning, no depth or opportunities to really think." Here is further evidence of inconsistent and muddled thinking.

\subsection{Trainees' concerns}

Some concerns were raised by the students which had also emerged in the questionnaires about the assessment and teaching of creativity.

"My major concern is that creativity is squashed by the education system we currently have. Assessment gets in the way because students have to get a certain response. Also, "Can you actually instruct people in creativity because by trying to teach it aren't you just squashing their own or putting yours onto them, trying to give them a rigid set of rules for being creative? It seems to be contradictory."

Two trainees highlighted assessment procedures as being barriers to creativity in the English classroom. One participant was disappointed that his experience in schools had revealed that pupils are often unwilling to take the creative opportunities of free choices and would prefer more structured guidelines or rigidly defined titles for post- 16 coursework, for example. This seemed to belie a lack of confidence due to the habitual dependency associated with earlier experiences of teaching and learning: "creativity must mean the production of something new - something original - and they seem to be wary of offering the wrong answer if they're doing something that's not been rehearsed in advance."

\section{Discussion}

\subsection{Limitations}

First, some limitations of the study need to be emphasised. This study has offered a focused view into a small group's ideas about creativity in English teaching and learning in the United Kingdom. If the sample had been larger additional conceptions may have emerged. While the findings may not be generalisable, there are conceptions here which other teacher trainers will recognize within their own students and this may inform how we teach others who are training to teach their native language and literature. In other words, this study has value because, in terms of 'relatability' (see Bassey, 2001), trainers will perhaps find that they can relate their experiences and the conceptions of their students to these findings. On this basis, themes emerge which should form the basis for some useful discussion.

\subsection{Conceptions and Strategies}

The data reveals that many of Sternberg's 21 suggested strategies for "Developing creativity as a decision" (Sternberg, 2003 , pp. $110-123$ ) have been addressed at least in part by some of the participant trainees in this group. There was 
evidence that some trainees understood the value of cross-curricular work, engaging and enjoyable activities and the positive effect of teacher modelling. Sternberg's distinction between the 'big C' and 'little c' creativity (Sternberg, $1999,2003)$ relates to the students' conceptions of the teacher's role:

"On the one hand, one cannot be creative without knowledge. Quite simply, one cannot go beyond the existing state of knowledge if one does not know what the state is. Many children have ideas that are creative with respect to themselves, but not with respect to the field because others have had the same ideas before. Those with a greater knowledge base can be creative in ways that those who are still learning about the basics of the field cannot be" (Sternberg, 2003, p.173).

Pupils and teachers need to be flexible, 'big C' Creativity unsettles frameworks but we need to have a secure grounding in our knowledge and understanding of them before we can go further. As teacher trainers it is clear that we need to foster a more pedagogically sound view which incorporates both the need for a knowledge and understanding of techniques, rules and structures whilst facilitating creative work by allowing freedom and choice where appropriate. Thus pupils will be taught and learn how to apply their knowledge of literary and linguistic techniques in English accurately, appropriately and creatively.

A key theme which emerged from the trainee's responses related to Sternberg's strategy as regards "Tolerance of Ambiguity" (Sternberg, 2003, p.115) but this was also the source of some misconceptions about the nature of English. Conceptions which related to questioning and curiosity as evidence of creativity were promising and part of the riskiness of English is due to its creative possibilities. Both original writing and interpretation of literary texts require subjective and personal responses and pupils fear they may be wrong, or exposed. Confidence building in English lessons is vital, therefore, as is an ethos of empathy and mutual support. Children have to respect one another in an effective English classroom. "Children need to be taught that uncertainty and discomfort are a part of living a creative life" (Sternberg, 2003, p.116). Some ideas are not black or white, some ideas are not immediately right or wrong and exploration of texts is at the heart of English teaching. Therefore, helping "Children Build Self-Efficacy" is part of the teacher's role: (Sternberg, 2003, p.118). However, this view must work alongside a tempering of the "anything goes" ideas expressed by some trainees. Children need to be open to teacher, peer and self evaluations which may highlight mistakes. Confidence is necessary if pupils are to thrive in a constructively critical environment; thus they will be enabled to hone and craft their creativity into valued work. There was evidence that trainees from this cohort understood that creating a climate where creativity is both encouraged and valued will build confidence and self-belief. However, there was less emphasis on the idea of valuing creative work through self, peer and teacher review. Careful textual analysis takes time and depends on a foundational knowledge and understanding of the use and effect of language in order to evaluate the author's choices and form an interpretation of meaning. Similarly, original writing can be deemed as valuable if there is a use of language drawn from knowledge and understanding of the effect and impact of literary techniques which then creates meaning, pleasure and engagement for a reader.

In response to the trainees' concerns we need to "Encourage Sensible Risk-taking" (Sternberg, 2003, p.114) and allow space and time wherein children can learn despite the pressures of assessment. Teaching to the test may be playing safe in the short term but this does not empower children or enable them to become independent learners. We do need to "Instruct and Assess for Creativity" (Sternberg, 2003, p. 119). A sensible method would be to implement a balanced approach. Assessment objectives need to be transparent and teaching constructively aligned. At the same time we must encourage pupils to think for themselves by allowing them the freedom to play with ideas and to take risks, in order to offer independent, thoughtful and insightful responses as long as these are justified and defendable.

\subsection{Pedagogical implications: Areas for development}

The benefits of questioning, redefining problems and problem-solving relates to Sternberg's notion of "choice" (Sternberg, 2003, p. 110). The idea of asking oneself questions and providing a rationale for creative work is sound. The value of giving children the opportunity to recognise and reflect upon mistaken choices was not addressed by any of the trainees in this group (Sternberg, 2003, p.111). The development of this analytical skill offers pupils the chance to redefine or refine choices; this would be closely aligned with the learning objectives outlines in the new Framework for English (DfES, QCA, 2008). Weston (2007) also suggests that we reframe problems in order to see them as opportunities for autonomous or collaborative learning. Negotiating different pathways around an obstacle or side-stepping in order to think laterally, "outside the box" are useful suggestions if we are to re-evaluate our notion of a problem.

Analytical thinking, critical questioning and reflection was largely a neglected area. Helping children to decide which assumptions are worth questioning is also important. It would be a waste of time and energy to debate the whys and wherefores of our idiosyncratic grammatical rules or spellings, for example. Nevertheless, commonly held beliefs which may lead to oppression or tolerance of inequality in any form must be held up for scrutiny in the English classroom. There is pedagogical value in encouraging children to ask the right questions. 
Only one trainee from this group thought about the practical conditions for creativity in terms of physical, external spaces: a flexible arrangement of tables in the classroom for group work and drama activities and using the classroom walls as a space for celebration by displaying children's creative work. This means of publication is motivating, encouraging and builds confidence. It is a powerful strategy and far more effective for creating the conditions necessary for creativity than a display of film poster or book covers. A focus on the ideal "environment" for creative teaching and learning emerges, then, as an area for further attention (Sternberg, 2003, p.122).

"Encourage Creative Collaboration" and "Imagine Things from Others' Points of View" (Sternberg, 2003, p. 121-122) are two related strategies which were largely neglected by the trainees in this cohort. Understanding how a character develops in fiction as well as entering into discussion with peers about potentially provocative subject matter will enable pupils to understand, respect and respond appropriately to others; this relates to 'empathy' in English which was addressed but only by two of the trainees. Encouraging collaborative creative work, Sternberg suggests, also provides an opportunity for children to imagine themselves in someone else's shoes (Sternberg, 2003, p. 122). Group work can be introduced in English lessons which will be difficult, challenging and perhaps frustrating; sustained collaborative and co-operative effort will create the opportunity for children to develop perseverance, patience, mutual support and encouragement. This will help to "Teach Children the Importance of Delaying Gratification" (Sternberg, 2003, p. 117). It takes time to build an argument, to ground critical analysis which rings true, to create a piece of writing or speaking which is effective and sometimes children need to reflect on unfinished work; here effort and discipline is its own reward as children learn to work steadily and step by step towards the final goal. An interim sense of achievement can be encouraged by asking children to look at how they have progressed in the short term. In English, pupils need to plan, draft, compose, review and edit their short stories or poems, for example. Children need to know that original writing is only a small percentage of inspiration and then a much larger percentage of craft and skill. Having a display of carefully finished work helps children to understand what is required for the final piece to be published. However, short term goals, interim review and constructive feedback is vital for maintaining motivation. Whilst we have looked at the benefits of quick thinking activities above, we also need to "Allow Time for Creative Thinking"; creative ideas sometimes need to be "incubated" (Sternberg, 2003, p. 119).

Another area which was not addressed by this cohort relates to the strategy of encouraging children to "Identify and Surmount Obstacles" (Sternberg, 2003, p.113). This connects to other strategies such as allowing mistakes, and taking responsibility for successes and failures (Sternberg, 2003, p. 120-121). Perseverance in the face of resistance, criticism or even hostility is an important life skill. Being creative has to be a long term project because it takes time for creative ideas to be accepted and valued; being creative often involves breaking the mould or, in Sternberg's terms "defying the crowd" (Sternberg, 2003, p.113). Children can be prepared to persevere if they are informed about possible obstacles they will encounter. They can be told stories about the sorts of resistance or obstacles met by other creative people in the field such as lack of parental support or poverty, or in extreme cases, exile.

\section{Conclusion}

To what extent these findings are context specific and would be different in other countries, cultures and languages remains to be seen and is open to study. Particularly interesting would be further studies of notions of creativity in first languages where two or more may exist side by side, as, for instance, in Canada or African countries. From within this cohort narrow ideas, inconsistent thinking and misconceptions have been revealed which will inform future teaching about creativity in Secondary School English. Notions about individuality, value and teacher intervention need to be addressed. Overly narrow conceptions of creativity need to be expanded and made more inclusive. We might also consider in future research whether inconsistent or conflicting views are evidenced in practice through observations of trainees' teaching in the classroom. Drawing on Sternberg's work might offer new dimensions to trainees' thinking about creativity in English teaching such as the importance of group work and collaborative learning, the need for perseverance, determination, hard work and the notion of creativity as process, critical thinking and its relationship to problem solving.

\section{Acknowledgements}

I owe many thanks to my colleague and mentor Professor Douglas Newton who has guided and supported me through the processes involved in the study and offered valuable feedback during the evolution and final production of this article.

\section{References}

Abbs, Peter. (1976). Root and Blossom: Essays on the Philosophy, Practice and Politics of English Teaching. London: Heinemann Educational Books.

Abbs, Peter. (1982). English within the Arts: A Radical Alternative for English and the Arts in the Curriculum. London, Sydney, Auckland and Toronto: Hodder and Stoughton.

Bassey, M. (2001). A solution to the problem of generalisation in educational research: fuzzy prediction. Oxford Review 
of Education, 22(1), 5-22.

Bloom, Harold \& Lionel Trilling. (1973). Romantic Poetry and Prose. New York and London: Oxford University Press.

Boden, Margaret. (Ed.). (1996). Dimensions of Creativity. Cambridge, Mass., London: The MIT Press.

Boden, M.A. (2004). The Creative Mind - Myths and Mechanisms. London: Routledge.

CACE (Central Advisory Council for Education). (1967). Children and their Primary Schools ('The Plowden Report'), London: HMSO. Full text available: Gillard, D (2004) . 'The Plowden Report', the encyclopaedia of informal education [Online] Available: http:// www.infed.org/schooling/plowden_report.htm (June 30, 2008).

Craft, A. (2002). Creativity and Early Years Education. London: Continuum.

Cox, C.B \& A.E. Dyson. (Eds., 1971). The Black Papers on Education. London: Dans-Poynter Ltd.

DfES (Department for Education and Skills). (2003). Excellence and Enjoyment. London: DfES.

Egan, Kieran. (1992). Imagination in Teaching and Learning ages 8-15. London: Routledge.

Fleming, Michael \& David Stevens. (1998). English teaching in the Secondary School: A Handbook for Students and Teachers. London: D. Fulton.

Fleming, Michael \& David Stevens. (2004). English teaching in the Secondary School: Linking Theory and Practice. London: D. Fulton.

Fleming, Michael. (2008). "Arts in education and creativity: a review of the literature." London: Creative Partnerships, Arts Council England, May 2008. [Online] Available:

http://cp-static.co.uk/static/PDFs/CPLitRev5_ArtsInEdCreativity.pdf (June 30, 2008).

Gardner, Howard. (1993). Multiple intelligences: The theory in practice. New York: Basic Books.

Harrison, Bernard. (1994). The Literate Imagination: Renewing the Secondary Curriculum in English. London: David Fulton Publishers.

Hall, Christine \& Pat Thomson. (2005). Creative tensions? Creativity and basic skills in recent educational policy in English in Education: Creativity and Change, Vol. 39, No. 3.

Hopkins, Charles. (1997). "Toronto Board of Education Curriculum Revision and Reorientation. ESD Case Study: Toronto, Canada, Board of Education. [Online] Available: http://www.esdtoolkit.org/discussion/case_study.htm (June 30, 2008).

Le Métais, J. O'Donnell, S., Boyd, S \& Tabberer, R. (1997). International review of Curriculum and assessment Frameworks: The Archive. London, School Curriculum and Assessment Authority. [Online] Available:

http://www.inca.org.uk/pdf/values_no_intro_97.pdf (June 30, 2008).

Marton, F. (1981) Phenomenography - describing conceptions of the world around us, Instructional Science, 10, 177-200.

NACCCE (National Advisory Committee on Creative and Cultural Education). (1999). All Our Futures: Creativity, Culture and Education. London: DfEE.

Newton, D.P. (2000). Teaching for Understanding. London: Routledge-Falmer.

Newton, D.P. \& Newton L.D. (in press). Some student teachers' conceptions of creativity in school science, Research in Science and Technology Education.

Ofsted. (2006). Creative partnerships: initiative and impact (Ref no. HMI 2517). London: Ofsted [Online] Available: http:// www.ofsted.gov.uk (June 30, 2008).

QCA (Qualifications and Curriculum Authority). (2003, 2005). Creativity: Find It! Promote It! London: QCA/DfEE.

QCA / DfCSF (2007, 2008). The Framework for Secondary English. Surrey, UK: Crown Copyright. [Online] Available: http://www.standards.dcsf.gov.uk/secondary/framework/english/fwse/ (June 30, 2008).

Robinson, Ken. (2001). Out of our Minds: Learning to be Creative. Capstone: Chichester.

SEED (Scottish Executive Education Department). (2006) Promoting creativity in education: overview of key national policy developments across the UK. [Online] Available: http://www.hmie.gov.uk/documents/publications/hmiepcie.html.

Sternberg, Robert. (Ed.). (1988). The Nature of Creativity: Contemporary psychological perspectives. Cambridge: Cambridge University Press.

Sternberg, Robert, J. (Ed.). (1999). Handbook of Creativity. Cambridge: Cambridge University Press. 
Sternberg, R.J. (2003). Wisdom, Intelligence and Creativity Synthesised. Cambridge: Cambridge University Press.

Weisberg, Robert W. (1986). Creativity: Genius and Other Myths. New York: W.H.Freeman and Company.

Weisberg, Robert W. (1993). Creativity: Beyond the Myth of Genius. New York: W.H.Freeman and Company.

Weston, Anthony. (2007). Creativity for Critical Thinkers. Oxford and New York: Oxford University Press.

\section{Appendix A}

Questionnaire given to17 trainee teachers before their first teaching practice (N.B. Spaces for responses have been omitted)

\section{Questionnaire: Conceptions of Creativity in Secondary School English}

- Do you think of English as a creative subject? Why do you think this?

- Can you give me an example of an English lesson you may have observed, participated in or taught recently which involved creativity? Which was the creative part? What was creative about it?

- Suppose you had to teach poetry in an English lesson. Are there opportunities for creativity in it? What are they? Can you explain what is creative about them?

- Suppose you had to teach punctuation in an English lesson. Are there opportunities for creativity in it? What are they? Can you explain what is creative about them?

- What would you give the lowest or no marks for?

- What would you look for as evidence of creative thought?

- Which English topics do you see as offering the best opportunities for creative thought? Put them in order with the best first.

- What makes your top choice the best?

- Do you think that encouraging creative thought in English is easy or hard? Why?

- Do you see problem solving as being related to creativity? In what way? Can you give me an example of a problem children might solve in English?

- So, in light of your responses above what would you say that creativity in English is about?

- Is there anything you want to add about creativity in English? Have I missed something out? 


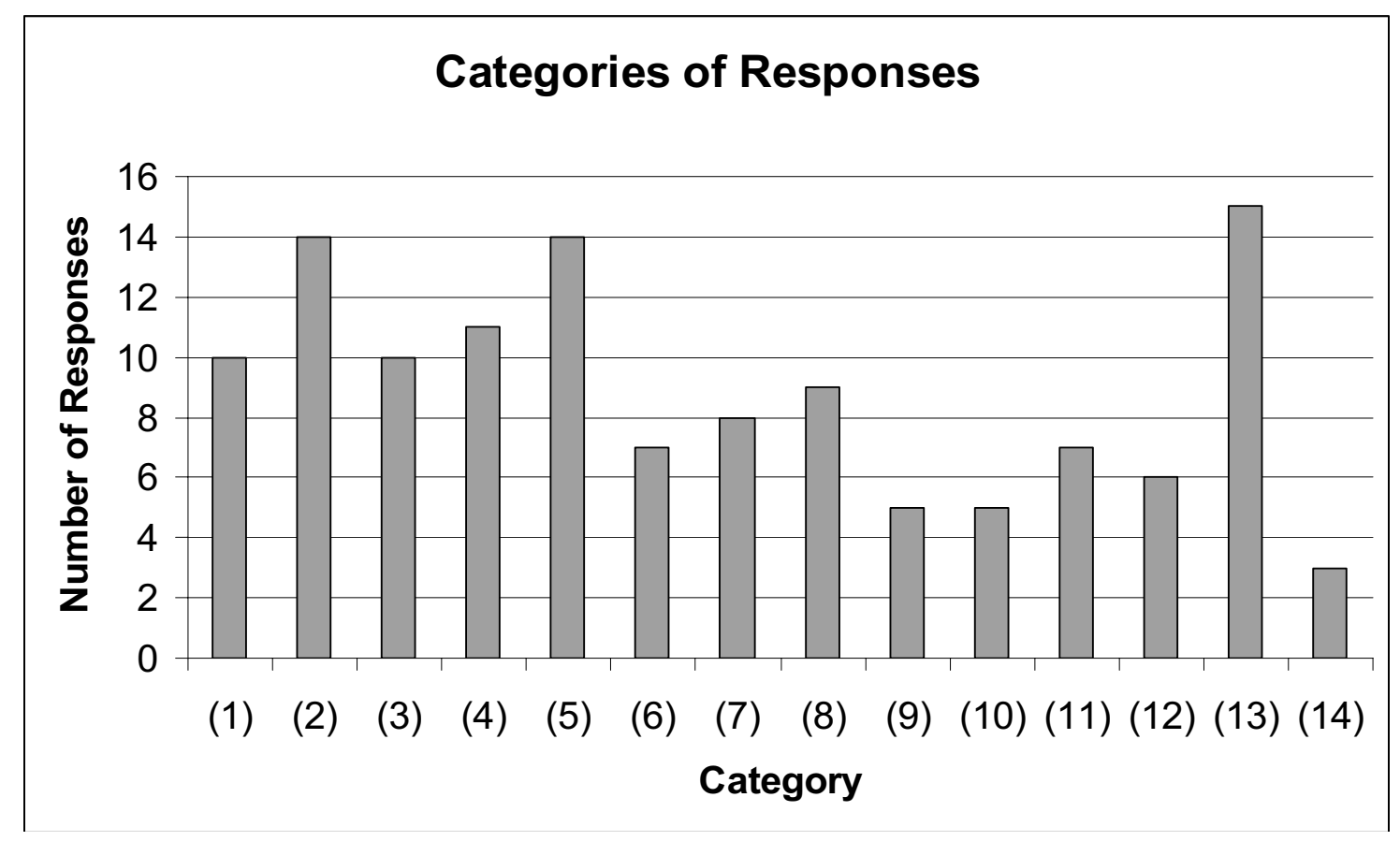

Figure 1. Categories of responses from Conceptions of Creativity Questionnaire (maximum possible in each category $=17$ ).

1) Key:

2) Personal construction of meaning

3) Construction of a novel product

4) Playing with language to create effect

5) Using imagination

6) Individuality / subjectivity / self-expression

7) Personality traits required (confidence- 6 , trust -1 )

8) Emotions, feelings

9) Original ideas, unexpected, unpredictable

10) Outside the box, way out, lateral or abstract thinking

11) Approaching things and seeing things from different points of view

12) Freedom of choice, no barriers or structure / frameworks

13) Need for frameworks / structure, teacher intervention

14) Need for teacher support, stimulation and facilitation

15) Discussion, debate, collaborative work 